\title{
POTENSI EUPHORBIA HETEROPHYLLA L. SEBAGAI INANG ALTERNATIF PENYAKIT KUDIS PADA UBIJALAR
}

\author{
Eko Agus Martanto ${ }^{1}$
}

\begin{abstract}
The Potential of Euphorbia heterophylla as an Alternative Host of Scab Disease on Sweet Potatoes. Scab, caused by Elsinoë batatas (Saw.) Jenkins \& Viegas, is a major disease on sweet potato. The disease cause reduction in tuber production up to $30 \%$. Euphorbia heterophylla is one of the common weeds in the cultivated land of sweet potatoes which is considered as an alternative host plant of the scab. The objective of this research was to study the ability of E. heterophylla as an alternative host of sweet potato. This study consisted of identification of sweet potatoes scab symptoms and $E$. heterophylla spot symptoms, isolation of the pathogen of sweet potato scab and E. heterophylla spot, and the test of pathogen virulence on some sweet potato cultivars. The result showed that the scab symptoms on sweet potatoes was brown and concaved caused by fungi E. batatas, while the spot symptoms on the E. heterophylla was white and convex caused by Fusarium sp. The cultivar of sweet potatoes which were inoculated with sick sweet potatoes suspension showed scab symptoms, however no symptoms occurred on the sweet potatoes which were inoculated with suspension of $E$. heterophylla. Overall, $E$. heterophylla was not considered to be the alternative host of scab on sweet potatoes.
\end{abstract}

Key words: Sweet potato scab disease, Euphorbia heterophylla, alternative host

\section{PENDAHULUAN}

Ubijalar (Ipomoea batatas (L.) Lamb.) adalah salah satu sumber pangan yang cukup potensial dalam mengatasi ketergantungan terhadap beras. Umbi ubijalar digunakan untuk konsumsi, baik sebagai makanan pokok maupun sebagai makanan sampingan (Semangun, 1991). Di Papua, sebagian besar penduduknya (60\%) menggunakan ubijalar sebagai makanan pokok terutama penduduk yang mendiami daerah pegunungan pada ketinggian 1500-2500 m dpl (Samori et al., 1998). Menurut Amir (1990), konsumsi ubijalar yang paling besar terdapat di Papua dengan 169,2 kg per kapita per tahun, diikuti Nusa Tenggara 32,2 kg per kapita per tahun, sedangkan di Jawa hanya 9,2 kg per kapita per tahun.

Secara nasional produksi rata-rata komoditas ubijalar mencapai 9,2 ton ha-1. Produksi ini lebih rendah bila dibandingkan dengan produksi rata-rata di Cina (17 ton ha ${ }^{-1}$ ) dan Malaysia (11 ton ha-1) (Nasrun et al., 1993). Rendahnya produktivitas ubijalar disebabkan oleh banyak faktor, salah satunya adalah penyakit kudis (scab) yang disebabkan oleh jamur Elsinoë batatas (Saw.) Jenkins dan Viegas (Floyd, 1988; Smit et al., 1991; Lenne, 1994). Kerugian yang ditimbulkan berupa penurunan produksi umbi sebesar $20-50 \%$ pada klon ubijalar rentan (Ramsey et al., 1988). Di Indonesia, produksi umbi klon ubijalar rentan yang terserang penyakit kudis mengalami penurunan hingga 30\% (Amir, 1988). Percobaan di Papua Nugini menunjukkan bahwa penyakit kudis menurunkan jumlah umbi $45 \%$, bobot umbi $26,5 \%$, produksi total $57 \%$, dan umbi yang bisa dipasarkan 34\% (Kanua \& Floyd, 1988).

Gulma adalah tumbuhan yang tumbuh di tempat yang tidak dikehendaki, tumbuhan yang tidak berguna, tidak diinginkan dan tidak disukai serta mengganggu pertumbuhan tanaman utama (Klingman, 1961 dalam Ronoprawiro, 1992). Gulma juga dapat berperan sebagai inang alternatif hama dan patogen, sehingga ketika tanaman tidak ada, hama dan patogen dapat hidup dan bertahan pada inang alternatifnya. Euphorbia heterophylla L. merupakan salah satu gulma yang umum ditemukan pada pertanaman ubijalar. Pada batang, tangkai daun dan daun gulma ini sering ditemukan gejala bercak yang mirip dengan gejala kudis pada ubijalar. Menurut Amir (1988) inang alternatif penyakit kudis ubijalar adalah genus Euphorbiaceae namun belum dibuktikan, sehingga masih diperlukan penelitian tentang masalah tersebut. Penelitian ini bertujuan untuk mengetahui potensi $E$. heterophylla sebagai inang alternatif penyakit kudis pada ubijalar.

\footnotetext{
${ }^{1}$ Fakultas Pertanian dan Teknologi Pertanian Universitas Negeri Papua

Jl. Gunung Salju Amban Manokwari Barat,Manokwari Papua Barat 98314. E-mail: e_a_martanto@yahoo.com
} 


\section{METODE PENELITIAN}

Penelitian dilakukan di Laboratorium Hama Penyakit Tumbuhan dan Rumah Plastik, Fakultas Pertanian dan Teknologi Pertanian, Universitas Negeri Papua, dari bulan Januari sampai April 2010.

Identifikasi Gejala di Lapang. Identifikasi gejala di lapangan dilakukan dengan cara pengamatan secara seksama terhadap gejala kudis yang terjadi pada ubijalar dan gejala bercak yang terdapat pada gulma E. heterophylla.

Isolasi dan Identifikasi Patogen. Isolasi patogen dilakukan dengan metode penanaman jaringan tanaman ubijalar dan E. heterophylla terinfeksi ke dalam media potato dextrose agar (PDA). Isolasi patogen dilanjutkan sampai diperoleh biakan murni. Selanjutnya, masing-masing biakan murni diidentifikasi dengan menggunakan acuan dari Barnett \& Hunter (1984) dan Alexopoulos \& Mims (1979).

Uji Virulensi di Rumah Plastik. Kegiatan ini bertujuan untuk mengetahui virulensi patogen pada kultivar ubijalar uji, baik patogen penyebab kudis pada ubijalar maupun penyebab bercak pada E. heterophylla. Bahan tanaman uji adalah 5 kultivar ubijalar dari kebun koleksi ubi-ubian Pusat Studi Ubi-ubian dan Sagu (PSUS) Unipa, yaitu kultivar Mandopi, Inanwatan, Helaleke, Bogor dan kultivar Wonembai. Percobaan menggunakan Rancangan Acak Lengkap, perlakuan diulang empat kali. Sampel tanaman yang diamati tiap ulangan berjumlah lima tanaman. Data yang diperoleh selanjutnya dianalisis secara tabulasi, untuk melihat terjadinya gejala pada masing-masing perlakuan.

Tanaman ubijalar berumur 1 minggu disemprot dengan fungisida Dithane M-45 dengan dosis $1 \mathrm{~g} \mathrm{lt}^{-1}$ air. Penyemprotan dilakukan agar tanaman ubijalar uji benar-benar bersih dari patogen, terutama patogen penyebab kudis. Satu minggu setelah penyemprotan fungisida, tanaman diinokulasi dengan suspensi patogen sesuai perlakuan. Suspensi patogen diperoleh dengan cara memblender $100 \mathrm{~g}$ bagian tanaman sakit dalam $100 \mathrm{ml}$ air steril dan disaring. Inokulasi dilakukan dengan cara menyemprotkan suspensi patogen ke permukaan tanaman, dan dilakukan dua kali dengan selang waktu tiga hari. Pengamatan intensitas penyakit dilakukan di sulur utama pada daun pertama sampai daun ke sepuluh dari pucuk. Pengamatan dilakukan satu minggu setelah inokulasi, diulang empat kali dengan selang pengamatan satu minggu. Intensitas penyakit dihitung dengan rumus:

$$
\mathrm{I}=\frac{\sum(\mathrm{nx} \mathrm{v})}{\mathrm{Z} \times \mathrm{N}} \times 100 \%
$$

Keterangan :

$\mathrm{I}=$ Intensitas penyakit

$\mathrm{n}=$ Jumlah tanaman tiap kategori serangan

$\mathrm{N}=$ Jumlah tanaman yang diamati

$\mathrm{v}=$ Nilai kategori serangan

$\mathrm{Z}=$ Kategori serangan tertinggi

Kategori serangan yang dipakai menurut Zuraida et al. (1992) yang dimodifikasi sebagai berikut:

$0=$ Sehat, tidak ada infeksi

$1=$ Bercak pada daun, tangkai daun dan batang $>0$ $20 \%$

$2=$ Bercak pada daun, tangkai daun dan batang $>20-$ $40 \%$

$3=$ Bercak pada daun, tangkai daun dan batang $>40-$ $60 \%$

$4=$ Bercak pada daun, tangkai daun dan batang $>60-$ $80 \%$

$5=$ Bercak pada daun, tangkai daun dan batang $>80 \%$

\section{HASIL DAN PEMBAHASAN}

Identifikasi Gejala. Dari hasil pengamatan diketahui bahwa gejala kudis pada ubijalar berupa bercak berwarna coklat, berbentuk bulat tidak beraturan, satu bercak dapat meluas dan akan bersatu dengan bercak yang lain. Gejala bercak pada E. heterophylla berwarna putih, berbentuk bulat tidak beraturan, bercak dapat meluas dan akan bersatu dengan bercak yang lain. Berdasarkan pengamatan gejala di lapang terhadap gejala kudis pada ubijalar dan bercak pada E. heterophylla, secara sepintas memang kelihatan hampir sama yaitu sama-sama terjadi bercak, baik pada batang, tangkai daun dan daun. Tetapi jika dilihat dengan lebih seksama ternyata ada perbedaan yang mendasar diantara kedua gejala tersebut. Gejala kudis pada ubijalar bentuknya cekung (Gambar 1A), sementara gejala bercak pada $E$. heterophylla bentuknya cembung (Gambar 1B). Gejala kudis pada ubijalar yang bentuknya cekung didukung hasil penelitian Martanto (2004) yang menyatakan bahwa setelah terjadi infeksi cendawan Elsinoe batatas penyebab kudis pada ubijalar, tanaman membentuk lapisan gabus di lapisan epidermis dan sub- 
epidermis. Pada perkembangannya, jaringan epidermis mati dan mengalami pengelupasan sehingga gejala kudis yang terjadi adalah cekung (Gambar 2A dan 2B).

Identifikasi Patogen. Pada media PDA, koloni cendawan dari ubijalar terinfeksi berwarna putih seperti kapas, berbentuk bulat tidak beraturan dengan miselium udara yang kompak (Gambar 3A). Hasil pengamatan dengan mikroskop perbesaran 1000x menunjukkan bahwa konidiumnya berbentuk bulat panjang, tidak bersekat, berukuran 6,6 x 3,9 $\mu \mathrm{m}$ (Gambar 3B). Berdasarkan hasil pengamatan makroskopis dan mikroskopis disimpulkan bahwa isolat yang diperoleh adalah cendawan E. batatas. Hasil ini didukung oleh Lenne (1994) dan Amir (1990) yang menyatakan bahwa penyakit kudis ubijalar disebabkan cendawan $E$. batatas dengan konidium berbentuk bulat panjang dan tidak bersekat.
Pada media PDA, koloni cendawan hasil isolasi dari E. heterophylla terinfeksi berwarna ungu dengan tepi koloni berwarna putih, berbentuk bulat tidak beraturan (Gambar 4A). Hasil pengamatan dengan mikroskop perbesaran empat ratus kali menunjukkan adanya dua jenis konidium, yaitu makrokonidium dan mikrokonidium. Mikrokonidium berbentuk oval tidak beraturan, jumlahnya sangat banyak, dan berukuran 8,1 x 3,9 $\mu$ m sedangkan makrokonidium berbentuk seperti bulan sabit, bersekat, jumlahnya lebih sedikit dan berukuran 27,3 x 4,5 $\mu \mathrm{m}$ (Gambar 4B). Berdasarkan hasil pengamatan makroskopis dan mikroskopis disimpulkan bahwa isolat yang diperoleh adalah cendawan Fusarium sp. Hasil ini didukung oleh Barnett \& Hunter (1984) yang menyatakan bahwa cendawan Fusarium mempunyai dua jenis konidium, yaitu mikrokonidium dan makrokonidium.

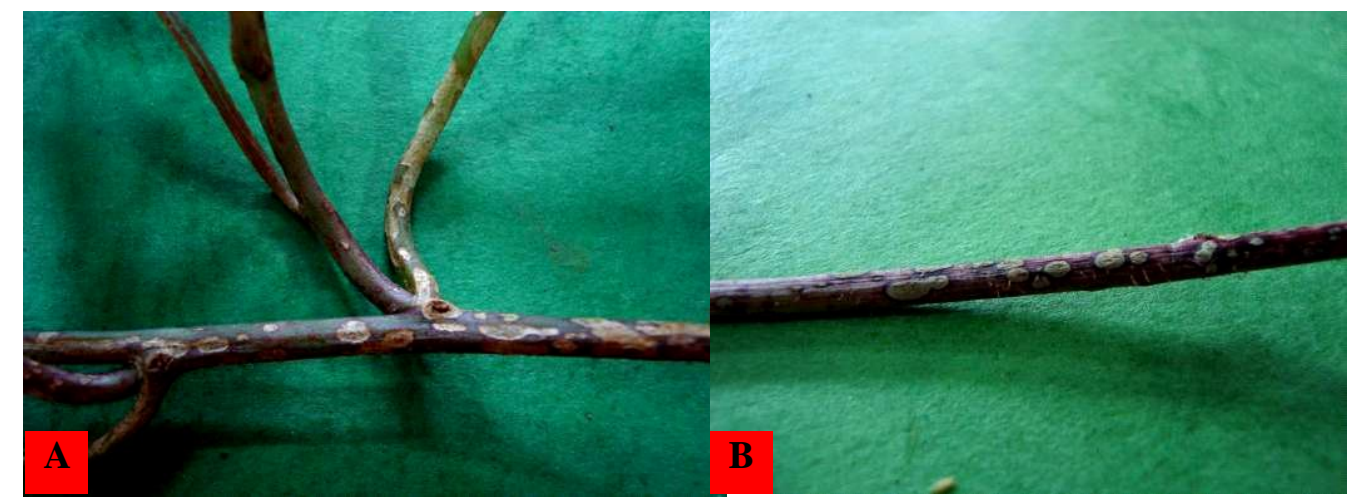

Gambar 1. A. Gejala kudis pada ubijalar berbentuk cekung; B. gejala bercak pada Euphorbia heterophylla berbentuk cembung
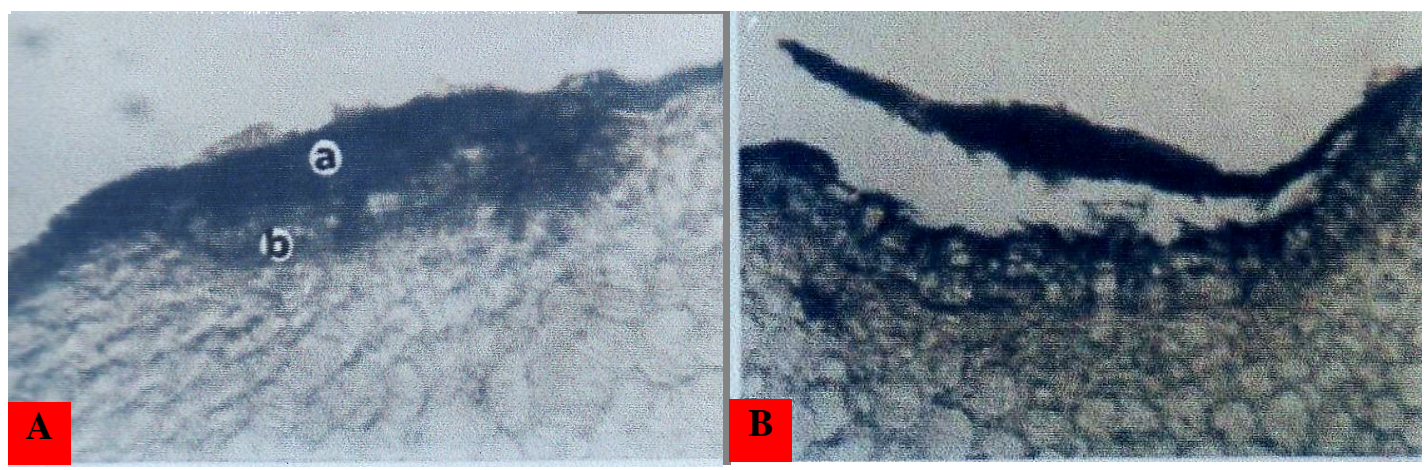

Gambar 2. A. Lapisan gabus di lapisan epidermis dan sub-epidermis daun ubijalar terinfeksi (a dan b); B. Jaringan epidermis mati dan mengalami pengelupasan sehingga gejala kudis yang terjadi adalah cekung 
Uji virulensi. Pada pengamatan pertama (hari ke-7) kultivar Mandopi dan kultivar Bogor yang diinokulasi dengan suspensi ubijalar sakit telah menunjukkan gejala, sedangkan pada kultivar lainnya belum tampak gejala. Gejala penyakit sudah tampak pada daun, terutama tulang daun pucuk. Gejala penyakit kudis pada tulang daun terlihat berupa bercak kecil, cekung dan berwarna coklat (Gambar 5A). Hal ini menunjukkan bahwa gejala pada jaringan muda lebih cepat tampak dari pada jaringan tua. Menurut Regis (1982 dalam Bajit \& Gapasin, 1987), jaringan muda tanaman ubijalar mempunyai jumlah stomata yang lebih banyak, jumlah lentisel yang lebih banyak, dan ketebalan kutikula yang lebih tipis sehingga lebih rentan terhadap infeksi patogen. Pada pengamatan berikutnya, intensitas penyakit kudis pada semua ubijalar tampak meningkat (Tabel 1). Pada waktu pengamatan yang sama, semua kultivar ubijalar uji yang diinokulasi dengan suspensi $E$. heterophylla terinfeksi tidak ada yang menunjukkan gejala penyakit kudis (Gambar 5B). Dengan demikian patogen penyebab bercak pada E. heterophylla tidak berpotensi menyebabkan penyakit kudis dan bukan sebagai inang alternatif penyakit kudis pada ubijalar. Hasil ini didukung oleh pernyataan Baliadi (1994) yang menyatakan bahwa penyakit kudis pada ubijalar hanya dapat disebabkan oleh infeksi cendawan Elsinoe batatas.

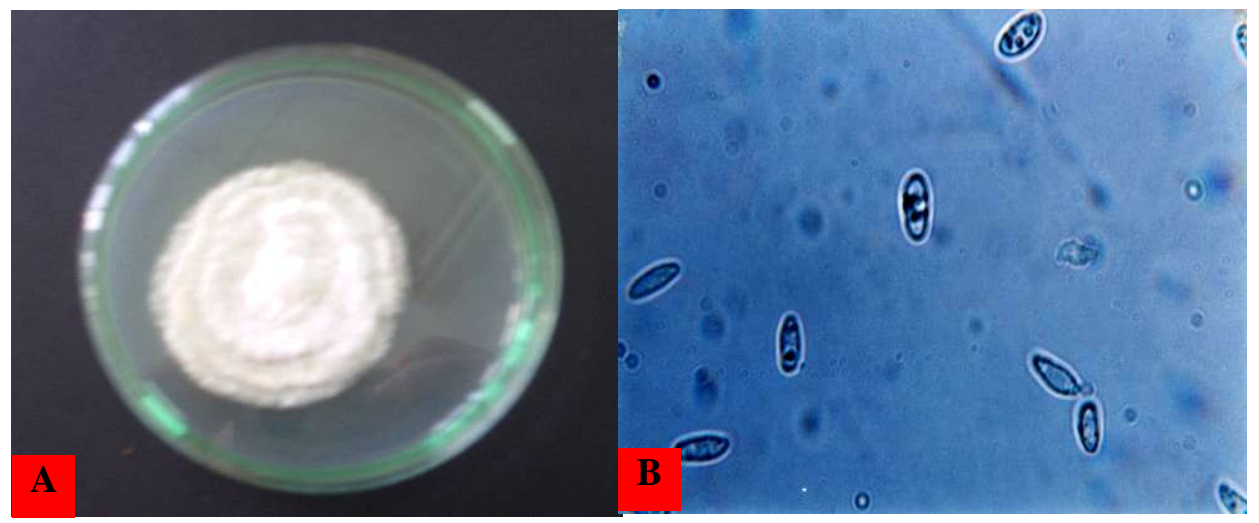

Gambar 3. Cendawan Elsinoe batatas A. Koloni berwarna putih; B. Konidium dengan perbesaran 1000x

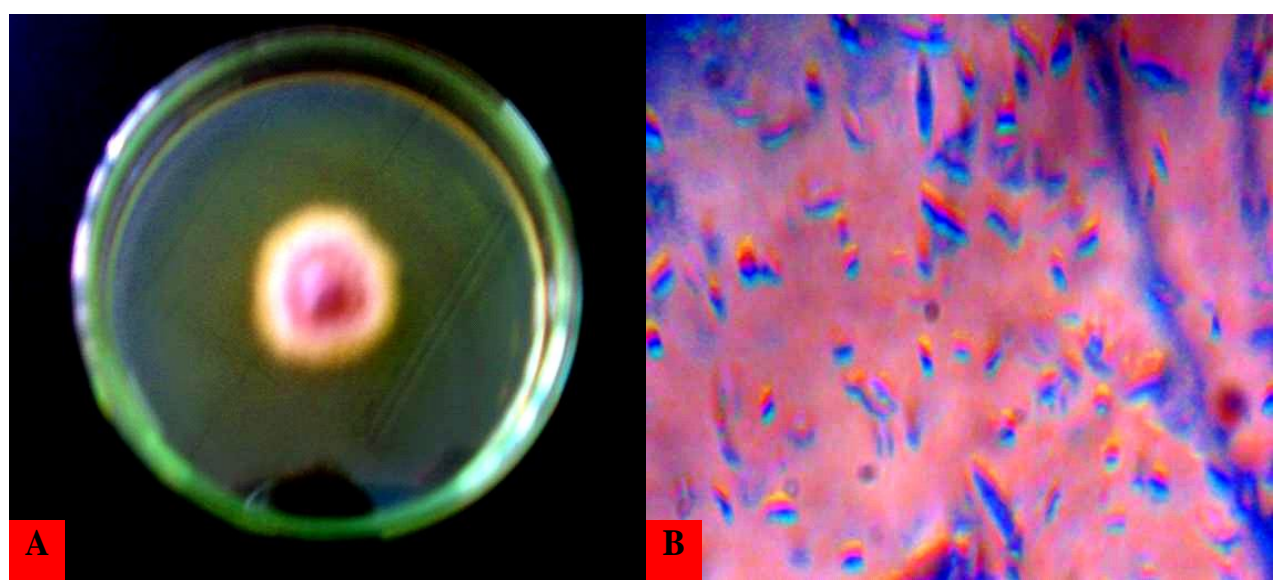

Gambar 4. A. Koloni cendawan Fusarium sp.berwarna ungu dengan tepi koloni berwarna putih; B. konidium dengan perbesaran 400x 


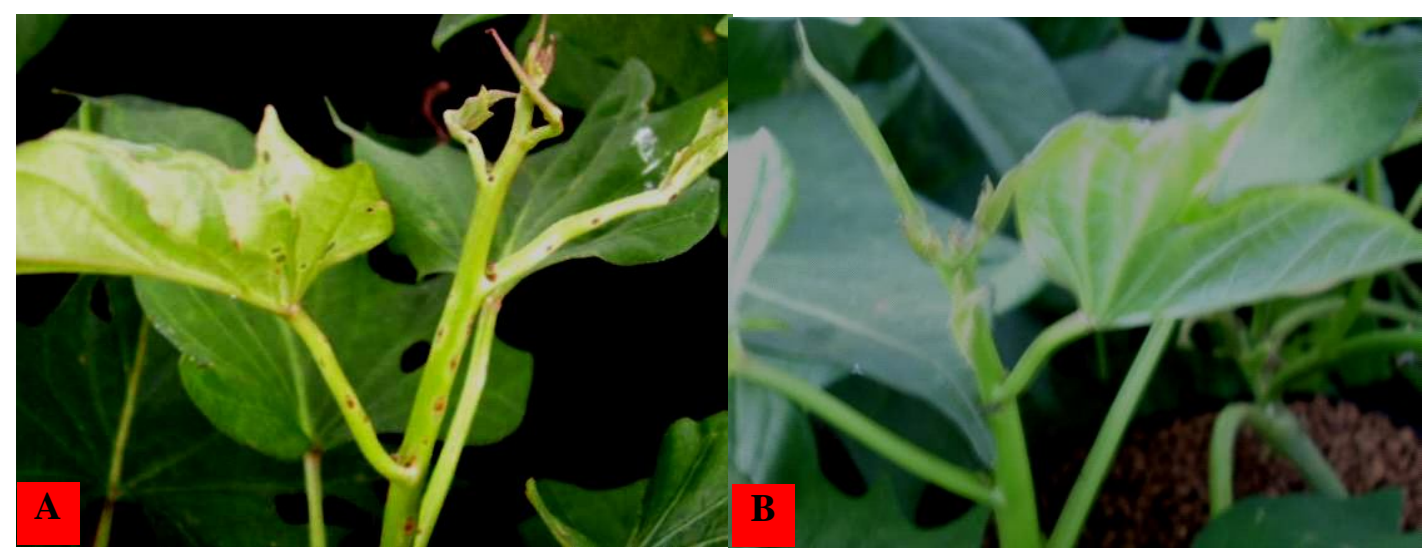

Gambar 5. Tanaman ubijalar kultivar Mandopi A. Diinokulasi dengan ekstrak tanaman ubijalar terinfeksi; B. Diinokulasi dengan ekstrak tanaman E. heterophylla terinfeksi

Tabel 1. Intensitas penyakit kudis pada kultivar ubijalar yang diinokulasi dengan ekstrak tanaman ubijalar terinfeksi dan E. heterophylla terinfeksi

\begin{tabular}{|c|c|c|c|c|c|c|c|c|}
\hline \multirow{3}{*}{ Kultivar } & \multicolumn{8}{|c|}{ Intensitas penyakit kudis (\%) pada ubijalar pengamatan ke } \\
\hline & \multicolumn{4}{|c|}{$\begin{array}{c}\text { Diinokulasi dengan ekstrak tanaman } \\
\text { ubijalar terinfeksi }\end{array}$} & \multicolumn{4}{|c|}{$\begin{array}{c}\text { Diinokulasi dengan ekstrak } \\
\text { tanaman E. heterophylla terinfeksi }\end{array}$} \\
\hline & 1 & 2 & 3 & 4 & 1 & 2 & 3 & 4 \\
\hline Mandopi & 8,04 & 12,63 & 16,50 & 22,05 & 0 & 0 & 0 & 0 \\
\hline Inanwatan & 0 & 4,06 & 9,00 & 11,50 & 0 & 0 & 0 & 0 \\
\hline Helaleke & 0 & 2,09 & 6,50 & 9,30 & 0 & 0 & 0 & 0 \\
\hline Bogor & 3,33 & 7,15 & 15,63 & 20,85 & 0 & 0 & 0 & 0 \\
\hline Wonembai & 0 & 3,61 & 7,88 & 11,90 & 0 & 0 & 0 & 0 \\
\hline
\end{tabular}

Keterangan : $1=7$ hari setelah inokulasi $(7 \mathrm{hsi})$

$2=14$ hari setelah inokulasi (14 hsi)

$3=21$ hari setelah inokulasi $(21 \mathrm{hsi})$

$4=28$ hari setelah inokulasi ( $28 \mathrm{hsi})$

\section{SIMPULAN}

Gejala kudis pada ubijalar berwarna coklat, cekung dan disebabkan oleh cendawan Elsinoe batatas, sedangkan gejala bercak pada Euphorbia heterophylla berwarna putih, cembung, dan disebabkan oleh Fusarium sp.. Kultivar ubijalar yang diinokulasi dengan suspensi ubijalar sakit menunjukkan gejala kudis, sedangkan kultivar ubijalar yang diinokulasi dengan suspensi $E$. heterophylla sakit tidak menunjukkan gejala kudis. Dengan demikian E. heterophylla bukan sebagai inang alternatif penyakit kudis pada ubijalar.

\section{DAFTAR PUSTAKA}

Alexopoulos CJ. 1962. Introductory Mycology. $2^{\text {nd }}$ Ed. John Willey, New York.

Amir M. 1988. Masalah Penyakit Kudis (Elsinoë batatas) pada Ubijalar dan Cara Pengendaliannya. Pp. 153 - 162 In: Paiki FA \& 
Matanubun H. Prosiding Seminar Ubi-ubian Irian Jaya, Manokwari, 27-29 Juli 1988.

Amir M. 1990. Studies on Sweet Potato Scab (Elsinoë batatas) in Indonesia. The International Workshop on Integrated Management of Diseases and Pest of Tuber Crops, Bhubaneswar, India.

Bajit GB \& Gapasin RM. 1987. Relationship Between Morphological Characteristics and Varietal of Sweet Potato to Scab Infection Caused by Sphaceloma batatas Saw. Annu. Trop. Res. 9(2): 75-83.

Baliadi Y. 1994. Bioekologi dan Upaya Pengendalian patogen Sphaceloma batatas Pada Ubijalar. Risalah Seminar Penerapan Teknologi Produksi dan Pasca Panen Ubijalar Mendukung Agroindustri, Balai Penelitian Tanaman Pangan, Malang.

Barnett HL \& Hunter BB. 1972. Illustrated Genera of Imperfect Fungi. Burgess Publishing Company, Minnesota.

Floyd CN. 1988. Control and Effect of Leaf Scab (Elsinoë batatas) on Sweet Potato. Trop. Agric. (Trinidad) 65(1): 6-8.

Kanua MB \& Floyd CN. 1988. Sweet Potato Genotype $x$ Environment Interactions in The Highlands of Papua New Guinea. Trop. Agric. (Trinidad) 65(1): 9-15.

Lenne JM. 1994. Diseases and Pests of Sweet Potato. Bull. Nat. Res. Inst. 46: 50-51.
Martanto EA. 2004. Interaksi Inang Patogen pada Penyakit Kudis Ubijalar (Elsinoe batatas). Disertasi. UGM Yogyakarta. (Tidak dipublikasikan).

Nasrun P, Jaswandi \& Jusuf M. 1993. Ketahanan Klon Harapan Ubijalar terhadap Scab (Elsinö̈ batatas). Risalah Seminar Balittan Sukarami II: $138-144$.

Ramsey MD, Vawdrey LL \& Hardy J. 1988. Scab (Sphaceloma batatas) a New Disease of Sweet Potato in Australia; Fungicide and Cultivar Evaluation. Aust. J. Exper. Agric. 28(1): 137141.

Ronoprawiro S. 1992. Gulma sebagai Lawan dan Kawan dalam Kehidupan Manusia. Pidato Pengukuhan Guru Besar dalam Ilmu Pertanian pada Fakultas Pertanian UGM, Yogyakarta.

Samori P, Paiki FA \& La Musadi. 1998. Kajian terhadap Penyakit Kudis Elsinoe batatas pada Berbagai Kultivar dan Sistem Budidaya Ubijalar di Lembah Baliem Wamena. Hyphere. Jurnal Ilmiah Ubiubian dan Sagu 3(1): 1-7.

Semangun H. 1991. Penyakit-Penyakit Tanaman Pangan di Indonesia. Gadjah Mada University Press, Yogyakarta.

Smit NEJM, Holo T \& Wilson JE. 1991. Sweet Potato Seedling Test for Resistance to Leaf Scab Disease (Elsinoë batatas). Trop. Agric. (Trinidad) 68(3): 263.

Zuraida N, Bari A, Wattimena GA, Amir M \& Soenaryo R. 1992. Pengaruh Penanaman Campuran Klon Ubijalar terhadap Penyakit Kudis dan Hasil. Penelitian Pertanian 12(3): 119-121. 